(C) Р.В. Кірчук, к.т.н.

Луцький національний технічний університет

Я.В. Оласюк, В.О. Хвесик, Ю.А. Хомич

Любешівський технічний коледж Луцького національний технічний університет

\title{
АНАЛІЗ МЕТОДІВ І ЗАСОБІВ ІНТЕНСИФІКАЦІЇ СУШІННЯ СІЛЬСЬКОГОСПОДАРСЬКИХ РОСЛИННИХ МАТЕРІАЛІВ
}

У статті наведено огляд та виконано аналіз методів $i$ засобів інтенсифікації сушіння сільськогосподарських рослинних матеріалів. Представлено конструкиії елементів сушарок, щүо дають можливість застосовувати енергозберігаючі підходи при отриманні продукиї агровиробнищтва. Сформовано загальну структурну схему напрямків енергозбереження при сушіння та засобів їх реалізащії.

СУШІННЯ, СУШИЛЬНИЙ АГЕНТ, СИПКИЙ МАТЕРІАЛ, РУЛОН, ЕНЕРГОЗБЕРЕЖЕННЯ, ІНТЕНСИФІКАЦІЯ 
Постановка проблеми. Сушіння - найбільш енерговитратна та відповідальна складова процесу післязбирального обробітку продукції рослинництва. Зберігання отриманого врожаю різних сільськогосподарських культур без контролю і зниження його вологості до кондиційного значення $\epsilon$ неможливим. При цьому, процес сушіння зерна має відбуватися при дотриманні технологічних вимог і без втрат споживчо-якісних характеристик сільськогосподарського матеріалу. Саме тому складовими економічного ефекту від виробництва продукції рослинництва $\epsilon$, перш за все, використання енергоефективних методів, а саме - енергозберігаючого підходу формування технології післязбирального обробітку та сушіння.

За даними різноманітних досліджень в галузі теорії $\mathrm{i}$ практики сушіння, зокрема сушіння капіляро-пористих колоїдних тіл, якими $є$ сільськогосподарські матеріали, $50 \ldots 60 \%$ усіх енерговитрат складають витрати на післязбиральний обробіток продукції рослинництва і процес її сушіння в тому числі [1-7]. Тому дослідження спрямовані на пошук та обгрунтування нових методів енергозбереження при сушінні сільськогосподарських матеріалів $\epsilon$ актуальними та важливими завданнями, які дозволили б знизити собівартість кінцевої продукції.

Аналіз останніх досліджень і публікацій. На сьогодні, аналізуючи перебіг процесу сушіння капіляро-пористих колоїдних тіл, розрізняють два основні підходи - це аналітичні та емпіричні дослідження [6-10].

Аналітичні дослідження грунтуються на використанні теорії тепло-масопереносу. На основі такого класичного методу створено багато математичних моделей процесу сушіння. Однак, це потребує визначення багатьох теплофізичних коефіцієнтів для різних культур, спрощення та зменшення кількості вхідних параметрів в процесі числового експерименту, приведення поверхні сушіння до канонічної форми та багатьох інших допущень, що зменшують доцільність застосування таких моделей для агровиробничих потреб.

В свою чергу, емпіричні дослідження процесів сушіння сільськогосподарських рослинних матеріалів вимагають спеціалізованого обладнання, часу та додаткових витрат, що не завжди є можливим в реальних умовах сільського господарства. Такі результати поверхневі і вимагають уточнення.

Окрім того, згадані теоретико-експериментальні методи аналізу процесів сушіння у агровиробництві досягли свого максимуму $\mathrm{i}$ не дають суттєвого ефекту в формуванні 
енергозберігаючих технологій післязбирального обробітку продукції рослинництва. Варто було б приділяти більше уваги розробці механічних систем інтенсифікації процесів сушіння рослинних матеріалів залежно від фізико-механічних, теплофізичних та технологічних властивостей агросировини.

Мета дослідження - дослідити та встановити можливі шляхи формування енергозберігаючих технології післязбирального обробітку, зокрема сушіння, сільськогосподарських рослинних матеріалів. Виконати аналіз та систематизувати механічні засобів інтенсифікації сушіння залежно від властивостей оброблюваної сировини.

Результати дослідження. Кафедрою аграрної інженерії Луцького національного технічного університету виконано значний обсяг робіт щодо дослідження процесів сушіння різноманітних рослинних сільськогосподарських матеріалів. Аналіз отриманих результатів дозволяє сформувати чіткий алгоритм розробки та використання механічних засобів активізації вологовидалення в ході післязбирального обробітку продукції рослинництва в агросекторі. Це дало можливість, шляхом проведення структурного аналізу, запропонувати розробку та створення механічної системи інтенсифікації сушіння сільськогосподарських рослинних матеріалів. Модернізуючи існуючі типи сушарок, або ж проектуючи нові з використанням елементів механічної системи інтенсифікації процесу сушіння можливим є суттєво пришвидшити процес вологовидалення.

Одним із способів зниження енерговитрат на післязбиральний обробіток сільськогосподарського матеріалу є його підготовка до сушіння шляхом попередньої сепарації [11-13]. Такий підхід варто застосовувати для обробітку таких важкороздільних зв'язаних матеріалів, як ворох льону, що отриманий в процесі комбайнового збирання. Приклади реалізації засобів сепарації показано на рис.1.

Окрім сепарування шару матеріалу, для покращення умов перебігу процесу сушіння пропонується збільшувати площу контакту поверхні матеріалу і сушильного агента $[14,15]$. Це можна реалізувати, наприклад, шляхом поділу качана кукурудзи чи надрізання поверхні зернівки сої (рис.2). 


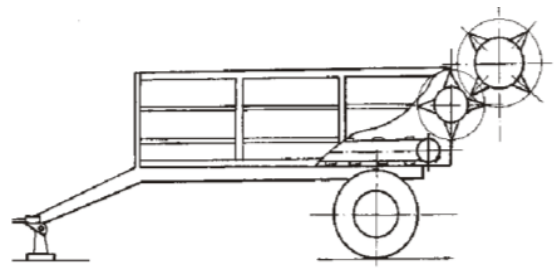

a)

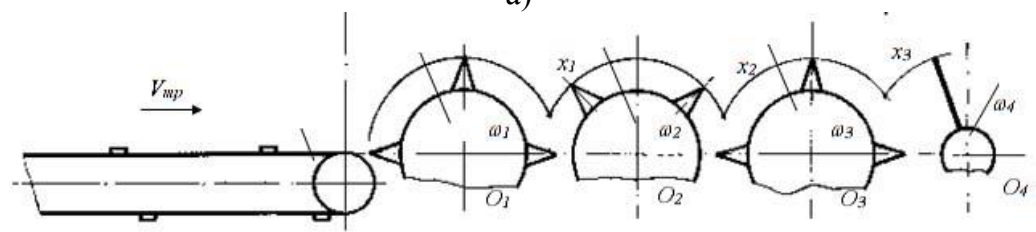

б)

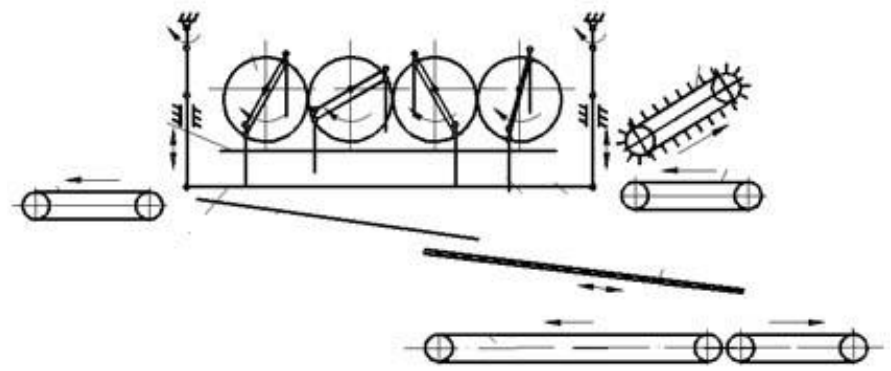

в)
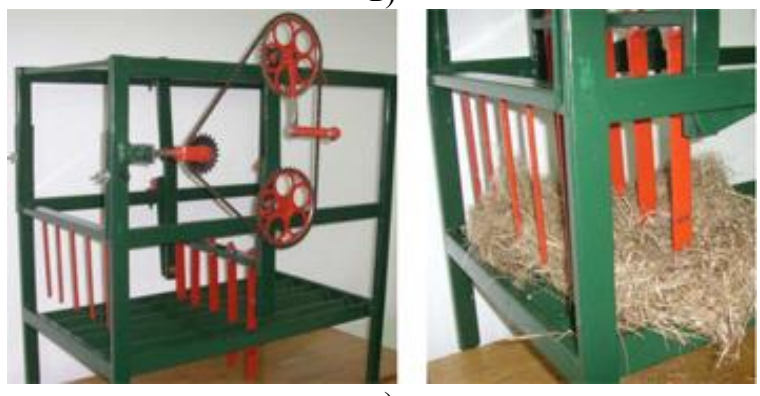

г)

Рис.1 - Сепаратори вороху льону: а - причеп-сепаратор; б - барабанний сепаратора; в - розтягуючий сепаратор; г - лабораторна установка для сепарації льоновороху 
Операція підготовки матеріалу до сушіння може бути технологічно суміщена з процесом завантаження сушарки. На рис.3 показано пристрої, які реалізують запропоновану технологію.

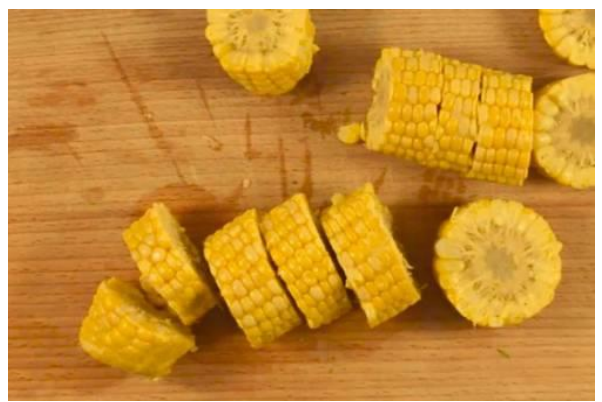

a)

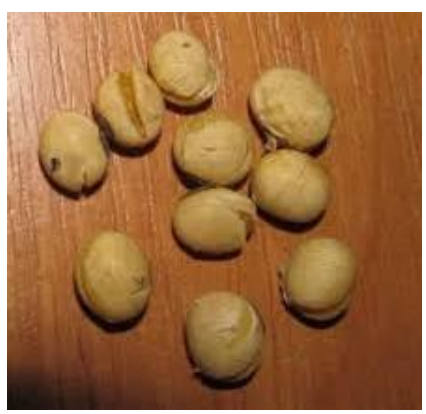

б)

Рис.2 - Подрібнені кукурудзяні качани (а) та надрізані боби сої (б)

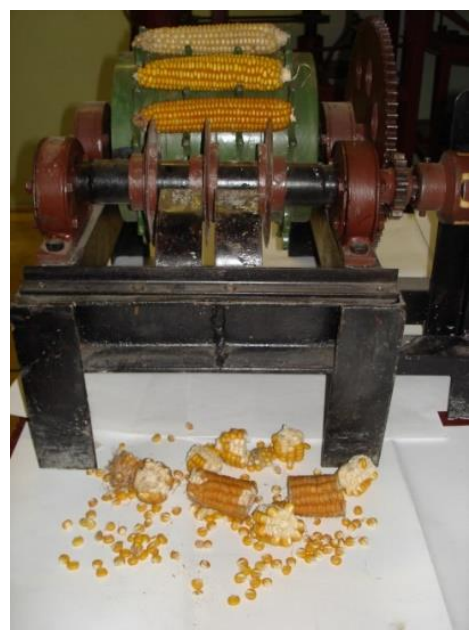

a)

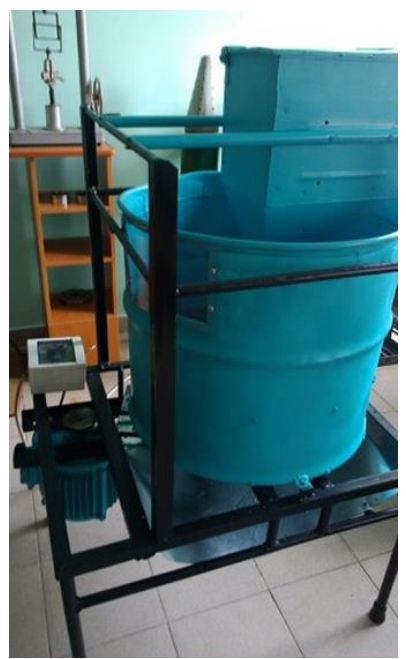

б)

Рис.3 - Лабораторні зразки для підготовки до сушіння качанів кукурудзи (а) та бобів сої (б)

Результати лабораторних досліджень свідчать про те, що такий метод інтенсифікації сушіння сільськогосподарських матеріалів може зменшити експозицію сушіння на 25-30\%. Його доцільно використовувати для сушіння продукції ненасіннєвого 
призначення. Отриманий матеріал потребує подальшої переробки наприклад, отримання соєвої олії.

Ще одним методом інтенсифікації видалення вологи 3 насіннєвого матеріалу є перемішування і розпушування його шару в процесі сушіння [16,17]. Такий підхід є доцільним для сипкого матеріалу при його сушінні у товстому шарі. Постійна зміна структури шару матеріалу не дозволяє утворюватись повітряним каналам, через які «висковзує» сушильний агент. Окрім того, перемішування і розпушування шару сприяє рівномірному вологовидаленню, не дозволяє пересушувати насіння, дозволяє використовувати м'які режими сушіння та отримувати якісний насіннєвий матеріал.

Дослідження процесів сушіння 3 постійною зміною структури товстого шару матеріалу проводились із насінням льону олійного, ворохом однорічних і багаторічних трав, насінням пшениці, ячменю та ріпаку. Функціональні схеми роботи таких методів сушіння у формі 3 -d моделей показано на рис.4, а фото сушарок, які реалізують таку технологію на рис.5.

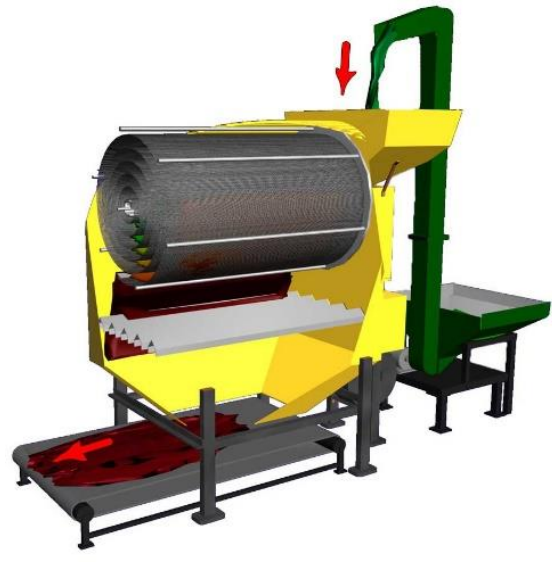

a)

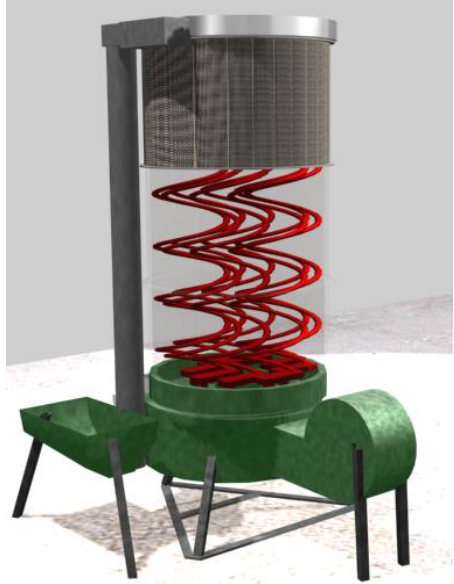

б)

Рис. 4 - 3-d моделі та схеми роботи сушарки сипких матеріалів 3 перемішуванням (а) та розпушування (б) шару матеріалу 


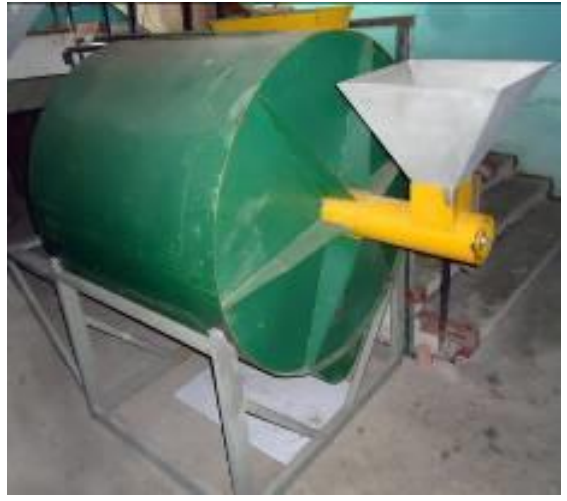

a)

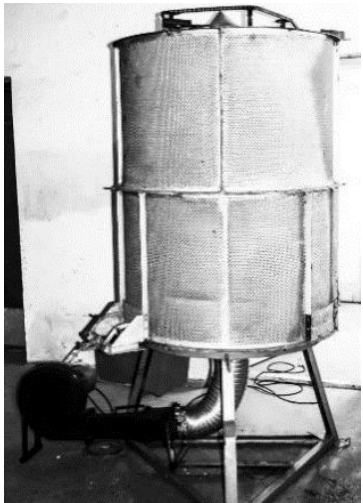

б)

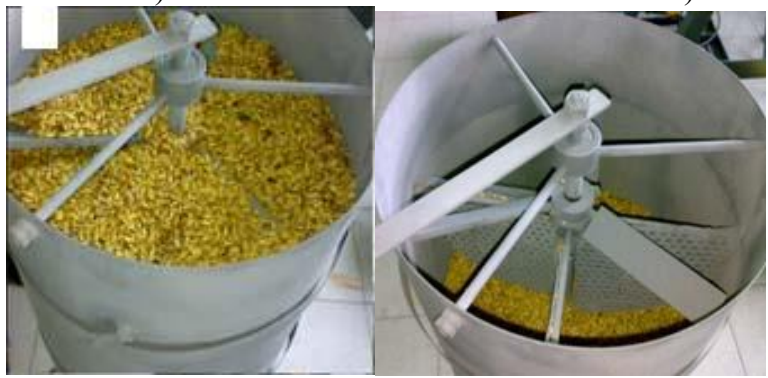

в)

Рис.5 - Загальний вигляд сушарок насіння трав (а), льону та ріпаку (б), зернових (в)

Сільськогосподарські матеріали в процесі їх збирання i первинного обробітку можуть бути сформовані у паковки. Найбільш технологічною паковкою $є$ рулон. Дослідження процесів сушіння рулонів льоносировини та рулонів соломи проведені у роботах $[18,19]$. Для забезпечення ефективного i рівномірного просушування таких сільськогосподарських матеріалів слід диференційованим чином підводити сушильний агент в зону сушіння залежно від структурних особливостей розміщення стеблової маси у паковці. Шари із більшою щільністю вкладання потребують більшої кількості сушильного агенту і навпаки - менш щільні шари сприймають менше витрату повітря. Схема сушіння та сушарка рулонів показані на рис.6. 


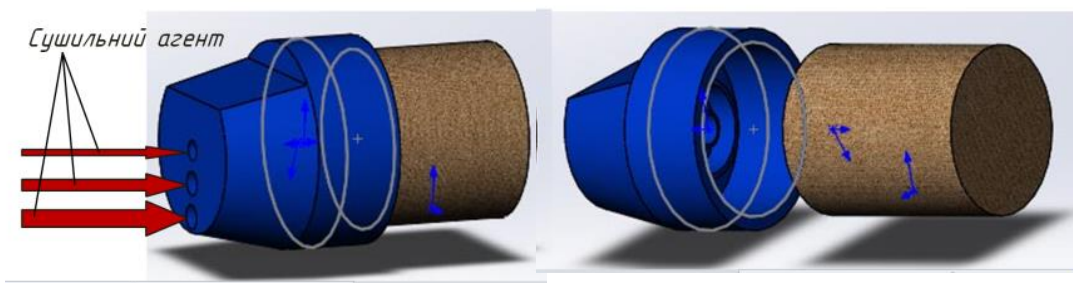

a)

б)

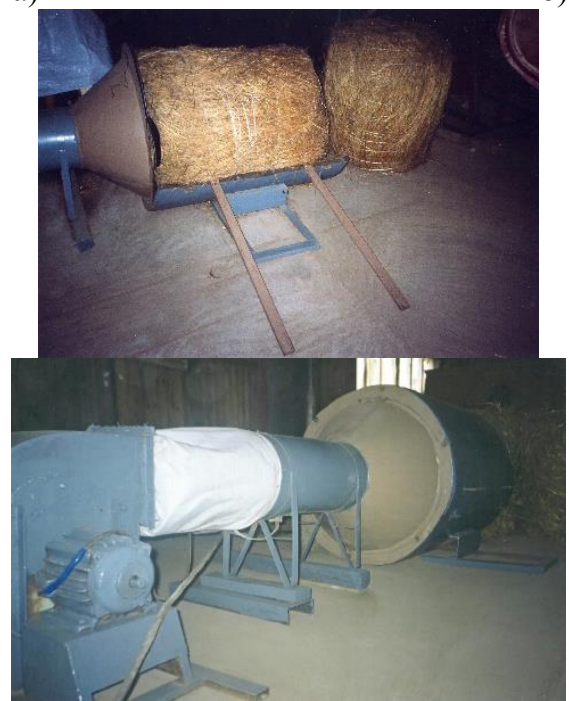

B)

Рис.6 - Схеми сушіння рулонів із диференційованим підводом сушильного агента (а), (б) та загальний вигляд сушарки (в)

Пошук шляхів зменшення вартості операції сушіння сільськогосподарської продукції не слід обмежувати лише впливом на матеріал, що піддається сушінню. Заслуговують на увагу методи підведення нагрітого повітря в зону сушіння, які дозволяють максимально використовувати потенціал сушильного агента. 3 висотою шару зерна у сушильній камері напор і швидкість агента сушіння знижується. Це призводить до нерівномірного просушування верхніх шарів. Для зменшення впливу цих факторів на якість процесу пропонується змінити циліндричну форму сушильної камери, яка $є$ звичною для більшості сушарок, на конічну. Такий прийом дозволить вирівняти витрату сушильного 
агента за усією вистою шару матеріалу, що просушується. Схема сушіння за даним методом показана на рис.7.

Висновоки. Аналіз отриманих результатів досліджень вказує на те, що для інтенсифікації сушіння сільськогосподарських рослинних матеріалів можна застосовувати технічні засоби, які доповнюють технологічний процес сушіння, не потребують радикальних змін у конструкціях сушарок, не є матеріаломісткими виробами. Окрім того, застосування такої механічної системи впливу на перебіг процесу вологовидалення суттєво скорочує час роботи сушарки.

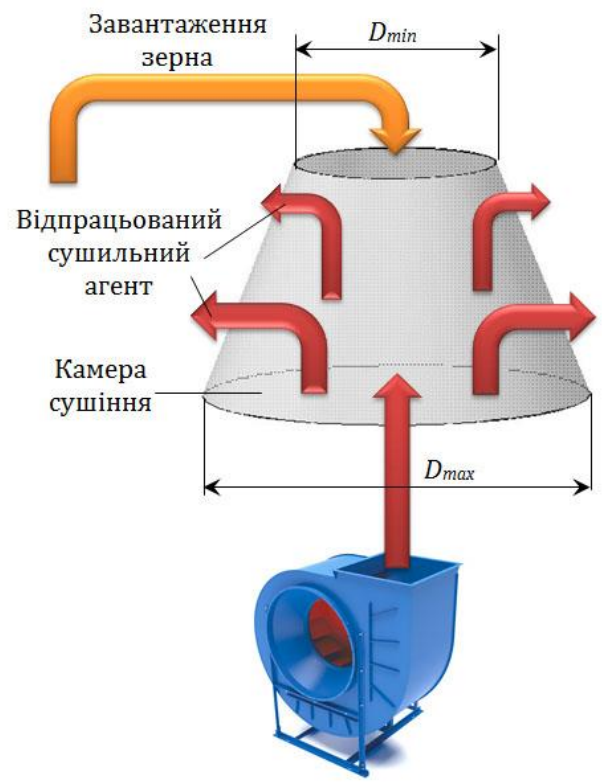

Рис.7 - Функціональна схема сушарки із конічною камерою сушіння

Загалом, методи енергозбереження та інтенсифікації сушіння агропродукції можна розділити таким чином:

- підготовка насіння до сушіння шляхом сепарації зв'язаного важкороздільного шару насіннєвого матеріалу;

- підготовка матеріалу до сушіння внаслідок поділу на дрібніші частини; 
- покращення умов вологовидалення через надрізання поверхні боба;

- зміна структури шару сипкого матеріалу в процесі сушіння;

- використання активаторів i розпушувачів шару спкого насіннєвого матеріалу;

- диференційований підвід сушильного агента в різні зони сушіння;

- формування оптимальних форм камер сушіння 3 позиції максимального використання потенціалу сушильного агенту.

\section{Література}

1. Гинзбург А.С. Проектирование установок для сушки пищевых продуктов. Москва: Агропромиздат, 1985. - 336 с.

2. Гинзбург А.С. Основы теории и техники сушки пищевых продуктов.- М,: Пищевая промышленность. $-1979 .-528$ с.

3. Кришер О. Научные основы техники сушки. М.: Иностранная литература, 1961. $540 \mathrm{c}$.

4. Котов Б.И. Технологические и теплоэнергетические основы повышения эффективности сушки растительного сырья: дис. ... доктора техн. наук: 05.20.01 / Борис Иванович Котов. - Глеваха, 1994. -440 с.

5. Дідух В.Ф. Підвищення ефективності сушіння сільськогосподарських рослинних матеріалів: монографія - Луцьк: ЛДТУ, 2002. -165 с. $600 \mathrm{c}$.

6. Лыков А.В. Теория тепловодности. М.: Высшая школа, 1967 -

7. Лыков А.В. Теория сушки / А.В. Лыков - М.: Энергия, 1968. $472 \mathrm{c}$.

8. Рудобашта С.П. Масоперенос в системах с твердой фазой. М.: Химия, 1980.248c.

9. Фролов В.Ф. Моделирование и сушка дисперсных материалов. Л.: Химия, 1987. - 208 с.

10. Гайвась Б. Математичне моделювання конвективного сушіння матеріалів 3 урахуванням механотермодифузійних процесів // Фізико-математичне моделювання та інформаційні технології. 2010, вип.12, 9-37с.

11. Подоляк В.М. Вдосконалення процесу сушіння вороху льону в нерухомому товстому шарі: автореф. дис. на здобуття наук. ступеня канд. техн. наук : спец. 05.20.01 «Механізація сільськогосподарського виробництва» / В.М. Подоляк; Луцьк, 1999.- 21c. 
12. Кірчук Р.В. Розробка сепаратора вороху льону: автореф. дис... канд. техн. наук: 05.05.11 «Машини і засоби механізації сільськогосподарського виробництва»/ Р.В. Кірчук; Луцьк,-2001.$19 \mathrm{c}$.

13. Тараймович І.В. Удосконалення технологічного процесу первинної обробки вороху льону-довгунця: автореф. дис... канд. техн. наук: 05.18.01 «Зберігання і технологія переробки зерна, виготовлення зернових і хлібопекарських виробів та комбікормів» / I.В. Тараймович; Херсон, 2009.- 25 с.

14. Панасюк С.Г. Обгрунтування параметрів технологічного процесу сушіння качанів кукурудзи: автореф. дис... канд. техн. наук: 05.05.11 «Машини і засоби механізації сільськогосподарського виробництва» / С.Г. Панасюк; Вінниця,-2008.- 20 с.

15. Розробка та обгрунтування параметрів пристрою підготовки зерен сої до сушіння : автореф. дис. ... канд. техн. наук : 05.05.11 «Машини і засоби механізації сільськогосподарського виробництва» / К.С. Копець;- Львів, 2016.- 20 с.

16. Забродоцька Л.Ю. Обгрунтування технологічного процесу та параметрів сушарки вороху насіння трав : автореф. дис. ... канд. техн. наук: 05.05.11«Машини і засоби механізації сільськогосподарського виробництва» / Л.Ю. Забродоцька; Кіровоград, 2012. - 22 с.

17. Ящук А.А. Обгрунтування параметрів сушарки насіння льону олійного : автореф. дис. ... канд. техн. наук : 05.05.11 / А.А. Ящук; - Кіровоград, 2014. - 20 с.

18. Федік Л.Ю. Вдосконалення технологічного процесу сушіння рулонів льонотрести : автореф. дис... канд. техн. наук: 05.20.01«Механізація сільськогосподарського виробництва» / Л.Ю. Федік; - Луцьк, 1999. - 15 с.

19. Дударєв I.М. Обгрунтування технологічного процесу та параметрів сушарки льоносировини в рулонах : автореф. дис... канд. техн. наук: 05.05.11«Машини і засоби механізації сільськогосподарського виробництва» / I.М. Дударєв; - Глеваха, 2007. - 19 c. 